\title{
Penentuan Rute Distribusi Untuk Meminimasi Biaya Distribusi di UKM Habil Snack
}

\author{
Mutiara Yetrina $^{1}$, Defby Seswita Nainggolan ${ }^{2}$ \\ ${ }^{1}$ Fakultas Teknik, Universitas Putra Indonesia "YPTK", Padang \\ email: mutiarayetrina17@gmail.com \\ ${ }^{2}$ Fakultas Teknik, Universitas Putra Indonesia "YPTK”, Padang \\ email: ndefbyseswita@gmail.com
}

\begin{abstract}
Habil Snack UKM is a balado chip food business. Determination of sub-optimal routes is one of the problems faced by this Habil Snack SME Distributor. Ineffective distribution route causes Habil Snack to bear the cost of gasoline. Planning for the order of product distribution routes is completely left to the decision of the driver, without planning based on logical considerations. Distribution time is too long, some shops visited exceed the working hours of the driver. This study applies the Saving Matrix method to optimize the distribution route. Data collection includes data on requests and distances between locations. Arrange a distance matrix based on distance data between locations. The Saving Matrix method is used to design routes based on the next closest distance. Distribution efficiency is evaluated based on the total distance, time and costs borne by UKM Habil Snack. The results showed that the distribution route shortened the distance by $8.4 \mathrm{~km}$.
\end{abstract}

Keywords: Distribution, schedule, route, Saving Matrix, Vehicle Routing Problem (VRP)

\begin{abstract}
Abstrak
UKM Habil Snack merupakan usaha pangan keripik balado. Penentuan rute yang kurang optimal merupakan salah satu masalah yang dihadapi oleh Distributor UKM Habil Snack ini. Kurang efektifnya rute distribusi menyebabkan UKM Habil Snack menanggung biaya bensin. Perencanaan urutan rute pendistribusian produk diserahkan sepenuhnya pada keputusan supir dan kernetnya, tanpa perencanaan yang dilandasi pertimbangan yang logis. Waktu pendistribusian terlalu panjang, beberapa toko yang dikunjungi melebihi jam kerja dari supir. Penelitian ini menerapkan dengan menggunakan metode Saving Matrix untuk mengoptimalkan rute pendistribusian. Pengumpulan data meliputi data permintaan dan jarak antar lokasi. Menyusun distance matrix berdasarkan data jarak antar lokasi. Metode Saving Matrix dipergunakan untuk merancang rute berdasarkan jarak terdekat berikutnya. Efisiensi pendistribusian dievaluasi berdasarkan total jarak, waktu dan beban biaya yang ditanggung oleh UKM Habil Snack. Hasil penelitian menunjukkan rute pendistribusian yang memperpendek jarak tempuh sejauh 8,4 km.
\end{abstract}

Kata kunci: Distribusi, jadwal, rute, Saving Matrix, Vehicle Routing Problem (VRP)

\section{PENDAHULUAN}

Habil Snack adalah suatu usaha industri kecil yang memproduksi snack berupa keripik balado, kue 88, beteng-beteng, keripik sanjai. Habil Snack ini berada di Jl. Banuaran, lubuk begalung. Dalam pendistribusian nya habil snack ini mendistribusikan produk nya ke beberapa kota di Provinsi Sumatera Barat.

Pada Habil Snack telah dipercaya untuk mendistribusikan produk ke berbagai daerah Jakarta dan Sumatra. Pengiriman produk dilakukan sesuai dengan permintaan masing-masing konsumen 
dengan menggunakan sarana transportasi darat dan laut. Selain itu, persediaan buffer yang ada ditetapkan berdasarkan permintaan terkecil yang terkadang persediaan tidak ada sama sekali selama masa pengiriman, yang mengakibatkan seringnya terjadi keterlambatan. Di dalam UKM ini belum adanya suatu perencanaan dan penjadwalan aktivitas distribusi produk yang terkoordinasi dengan baik sehingga permintaan untuk semua masing produk kurang terkontrol yang mengakibatkan terjadinya kekurangan atau kelebihan persediaan, baik pada UKM maupun pada masing-masing customer.

Salah satu untuk metode yang dapat diusulkan untuk memperbaiki rantai pasok dalam penjadwalan dan penentuan rute distribusi keripik balado yaitu Saving Matrix yang merupakan metode pejadwalan distribusi untuk meminimumkan rute yang ditempuh dengan mempertimbangkan kendala yang ada. Berdasarkan pertimbangan dan permasalahan diatas maka penelitian ini dilakukan untuk mengetahui penjadwalan dan rute distribusi barang di Habil Snack.

Penelitian ini bertujuan untuk menentukan penjadwalan dan penentuan rute distribusi pada rantai pasok untuk meminimasi biaya distribusi dengan menerapkan Metode Saving Matrix di UKM Habil Snack serta merencanakan rute distribusi produk keripik balado dengan menggunakan Vehicle Routing Problem (VRP) di UKM Habil Snack.

\subsection{Distribusi}

Distribusi adalah kegiatan untuk mentransfer produk dari rantai pasokan. Distribusi merupakan kunci keuntungan yang akan diperoleh perusahaan karena distribusi langsung akan mempengaruhi biaya dari supply chain dan kebutuhan konsumen, jaringan distribusi yang tepat dapat digunakan untuk mencapai berbagai macam kebutuhan pasokan rantai mulai dari biaya yang rendah dan respons yang tinggi terhadap permintaan konsumen.
Istilah distribusi sama dengan tempat (penempatan) yaitu aktivitas penyaluran atau penempatan barang (produk) dari produsen ke konsumen. Perpindahan material terjadi pada semua siklus proses pembuatan produk, baik sebelum proses selanjutnya produksi [1].

Distribusi mengacuh pada langkahlangkah yang diambil untuk memindahakan dan menyimpan produk dari tahap suplier ke tahap pelanggan dalam rantai pasokan.Distribusi terjadi antara setiap pasangan tahapan dalam rantai pasokan. Bahan baku dan komponen yang pindah dari pemasok ke produsen. Sedangkan produk jadi dipindahkan dari produsen ke pelanggan. Distribusi akhirnya adalah pendorong utama dari profitabilitas keseluruhan suatu perusahaan karena mempengaruhi baik biaya rantai pasokan dan pengalaman pelanggan secara tidak langsung [2].

\subsection{Transportasi}

Menurut Adisasmita [3], Transportasi berasal dari kata Latin yaitu transportare, dimana trans berarti seberang atau sebelah lain dan portare berarti mengangkut atau membawa. Jadi transportasi berarti mengangkut atau membawa (sesuatu) ke sebelah lain atau dari suatu tempat ke tempat lainnya. Ini berarti transportasi merupakan suatu jasa yang diberikan, guna menolong orang dan barang untuk dibawa dari suatu tempat ke tempat lainnya. Dengan demikian, transportasi dapat diberi definisi sebagai usaha dan kegiatan mengangkut atau membawa barang atau penumpang dari suatu tempat ke tempat lainnya. Dapat ditegaskan lagi bahwa transportasi adalah jasa yang dipergunakan sebagai alat untuk memperoleh keuntungan-keuntungan ekonomis dalam berbagai kegiatan usaha dan hubungan kemasyarakatan [4].

Dalam ilmu transportasi, alat pendukung transportasi diistilahkan dengan sistem transportasi yang di dalamnya mencakup berbagai unsur (subsistem) berikut: ruang 
untuk bergerak (jalan), tempat awal/akhir pergerakan (terminal), yang bergerak (alat angkut/kendaraan dalam bentuk apapun), pengelolaan yang mengkoordinasi ketiga unsur sebelumnya.

\subsection{Metode Pendistribusian Barang}

Berikut adalah macam - macam metode yang dapat digunakan untuk meminimumkan biaya transportasi terhadap input dan output yang dihasilkan perusahaan [5]:

\subsubsection{Vehicle Routing Problem (VRP)}

Vehicle Routing Problem (VRP) diperkenalkan pertama kali oleh Dantziq dan Ramser pada tahun 1959 dan semenjak itu telah dipelajari secara luas. Menurut Fisher [6], VRP didefinisikan sebagai sebuah pencarian atas cara penggunaan yang efisien dari sejumlah vehicle yang harus melakukan perjalanan untuk mengunjungi sejumlah tempat untuk mengantar dan menjemput orang atau barang. Istilah customer digunakan untuk menunjukkan pemberhentian untuk mengantar dan menjemput orang atau barang. Setiap customer harus dilayani oleh satu vehicle saja. Penentuan pasangan vehicle-customer ini dilakukan dengan mempertimbangkan kapasitas vehicle dalam satu kali angkut, untuk meminimalkan biaya yang diperlukan. Biasanya, penentuan biaya minimal erat kaitannya dengan jarak yang minimal [7]. VRP juga dapat dilihat sebagai kombinasi dari dua permasalahan optimasi lain, yaitu Bin Packing Problem (BPP) dan Travelling Salesman Problem (TSP). BPP dapat dideskripsikan sebagai berikut: "Diberikan sejumlah angka, yang melambangkan ukuran dari sejumlah item, dan sebuah konstanta K, yang melambangkan kapasitas dari bin. Berapa jumlah bin minimum yang diperlukan?" Tentu saja satu item hanya dapat berada dalam satu bin saja, dan total kapasitas item pada setiap bin tidak boleh melebihi kapasitas dari bin tersebut

\subsubsection{Saving Matrix}

Saving Matrix merupakan metode sederhana yang dapat diimplementasikan dan digunakan untuk pengiriman ke pelanggan. Pekerjaan pertama yang harus dilakukan adalah menentukan alokasi truk. Artinya, perlu diketahui truk mana yang akan mengunjungi toko yang mana. Tahap kedua nantinya adalah menentukan rute perjalanan masing-masing truk lalu di masukkan ke dalam salah satu metode yaitu metode Saving Matrix.

Metode Saving Matrix pada hakekatnya adalah metode untuk meminumkan jarak atau waktu atau ongkos dengan mempertimbangkan kendala-kendala yang ada. Karena di sini kita berbicara koordinat tujuan pengiriman maka masuk akal untuk menggunakan jarak sebagai fungsi tujuan. Artinya, kita akan meminumkan jarak yang ditempuh oleh semua kendaraan [8].

\section{METODE PENELITIAN}

Penelitian ini bersifat kuantitatif, dimana pada penelitian ini akan melakukan pengukuran meminimumkan biaya transportasi terhadap suatu perusahaan. Pada penelitian ini menggunakan data yang berbentuk angka-angka, dan datadata yang dihasilkan merupakan data yang diamati secara langsung. Penelitian ini menggunakan penelitian kuantitatif dimana penelitian kuantitatif merupakan metode untuk menguji teori-teori tertentu dengan cara meneliti hubungan antar variable.

Data sekunder merupakan sumber data yang tidak langsung memberikan data kepada pengumpul data. Data sekunder ini merupakan data yang sifatnya mendukung keperluan data primer. Data ini antara lain: Data permintaan pelanggan Data Biaya Transportasi, Data Jarak Antar Toko, dan Data Kapasitas Kendaraan.

Data yang digunakan dibatasi hanya pada data permintaan setiap agen. Data yang digunakan yaitu 3 jarak, ongkos dan rute distribusi untuk daerah Padang, 
Pekanbaru, dan Palembang. Pengolahan data dibagi menjadi 2 (dua) bagian besar, yaitu :

1. Menentukan penjadwalan dan penentuan rute distribusi pada rantai pasok untuk meminimasi biaya distribusi dengan menggunakan Metode Saving Matrix di UKM Habil Snack dengan cara:

a. Melakukan penggabungan yang dimulai dari nilai penghematan terbesar untuk memaksimumkan penghematan, dengan rumus:

b. Menentukan urutan kunjungan setelah alokasi retailer ke rute telah ditentukan, dimana rumus-rumus yang digunakan adalah dengan mengalokasikan konsumen ke kendaraan atau rute terdekat dengan memperhatikan Heterogeneous Fleet, dan mengurutkan Konsumen dalam Rute yang Sudah Terdefinisi dengan Memperhatikan Time Windows yang sudah ditetapkan konsumen.

2. Untuk merencanakan rute distribusi produk keripik balado dengan menggunakan Vehicle Routing Problem (VRP) dengan cara :

A. Berawal dari gudang, kemudian mencari lokasi pelanggan yang belum dikunjungi yang memiliki jarak terpendek dari gudang. Sebagai lokasi pertama.

B. Jarak terdekat dari lokasi yang terpilih sebelumnya dan jumlah pengiriman tidak melebihi kapasitas kendaraan.
a. Apabila ada lokasi yang terpilih sebagai lokasi berikutnya dan terdapat sisa kapasitas kendaraan, kembali ke langkah (II).
b. Bila kendaraan tidak memiliki sisa kapasitas, kembali ke langkah (I).
c. Bila tidak ada lokasi yang

terpilih karena jumlah pengiriman melebihi kapasitas kendaraan, maka kembali kelangkah (I). Dimulai lagi dari gudang dan mengunjungi pelanggan yang belum dikunjungi yang memiliki jarak terdekat.

\section{HASIL DAN PEMBAHASAN}

Hasil yang didapatkan dari proses pengolahan data adalah sebagai berikut:

\subsection{Penjadwalan dan Penentuan Rute} Distribusi

Dalam menentukan rute untuk meminimalkan rute dilakukan dengan metode saving matrix. Metode tersebut mampu membentuk rute dan urutan titik perhentian di dalam satu rute. Langkah awal yang dilakukan adalah mengidentifikasi matrix jarak antara gudang ke masing-masing toko dan jarak antar toko (Tabel 1).

Tabel 1. Jarak Antar Gudang Dan Toko

\begin{tabular}{|c|c|c|c|c|c|c|c|}
\hline & Gd & A & B & C & D & E & F \\
\hline Gd & 0 & 14280 & 1070 & 770 & 523 & 42 & 28 \\
\hline A & 14280 & 0 & 415 & 1962 & 860 & 1389 & 1443 \\
\hline B & 1070 & 415 & 0 & 1625 & 526 & 1055 & 1081 \\
\hline C & 770 & 1962 & 1625 & 0 & 1110 & 520 & 747 \\
\hline D & 523 & 860 & 526 & 1110 & 0 & 519 & 544 \\
\hline E & 42 & 1389 & 1055 & 520 & 519 & 0 & 28 \\
\hline F & 28 & 1443 & 1081 & 747 & 544 & 28 & 0 \\
\hline
\end{tabular}

Matriks jarak antar gudang dan toko tersebut dibuat dengan menggunakan Google Maps. Dengan bantuan Google Maps inilah didapatkan jarak dari gudang ke toko dan juga jarak antar toko (Tabel 2).

Tabel 2. Hasil Perhitungan Jarak Penghematan

\begin{tabular}{|c|c|c|c|c|c|c|c|}
\hline & Rute & $1 \mathrm{~A}$ & $1 \mathrm{~B}$ & $1 \mathrm{C}$ & $1 \mathrm{D}$ & $1 \mathrm{E}$ & $1 \mathrm{~F}$ \\
\hline $1 \mathrm{~A}$ & 1 & 0 & & & & & \\
\hline
\end{tabular}




\begin{tabular}{|c|c|c|c|c|c|c|c|}
\hline $1 \mathrm{~B}$ & 2 & 14935 & 0 & & & & \\
\hline $1 \mathrm{C}$ & 3 & 13088 & 752 & 0 & & & \\
\hline $1 \mathrm{D}$ & 4 & 13943 & 749 & 1041 & 0 & & \\
\hline $1 \mathrm{E}$ & 5 & 12895 & 749 & 2160 & 1111 & 0 & \\
\hline $1 \mathrm{~F}$ & 6 & 12865 & 777 & 1959 & 1313 & 1035 & 0 \\
\hline
\end{tabular}

\subsubsection{Usulan Penjadwalan Dan} Penentuan Rute Distribusi

Berdasarkan perhitungan dalam mengalokasikan toko kedalam rute atau kendaraan, setelah diketahui hasil perhitungan alokasi toko ke dalam rute atau kendaraan pengiriman yang dilakukan dengan 2 rute pengiriman : Rute $1=$ Go-D$\mathrm{B}-\mathrm{A}=1.420 \mathrm{Km}$ dan Rute 2 = Go- E- F-C $=56 \mathrm{Km}$, dimana Go adalah Gudang, $\mathrm{A}$ adalah Bogor, B adalah Lampung, C adalah Medan, D adalah Jambi, E adalah Warung B. Ida, dan F adalah Bandara.

Tabel 3. Rekapitulasi Jarak Tempuh Rute Distribusi

\begin{tabular}{|c|c|c|c|}
\hline Rute & Kode Rute & Jarak & Armada \\
\hline 1 & $\mathrm{G} 0 \rightarrow \mathrm{E} \rightarrow \mathrm{G} 0 \rightarrow \mathrm{F} \rightarrow \mathrm{G} 0 \rightarrow \mathrm{C}$ & 845,8 & Avanza \\
\hline 2 & $\mathrm{G} 0 \rightarrow \mathrm{D} \rightarrow \mathrm{G} 0 \rightarrow \mathrm{B} \rightarrow \mathrm{G} 0 \rightarrow \mathrm{A}$ & 4556 & L300 \\
\hline
\end{tabular}

Tabel 3. Rekapitulasi Jarak Tempuh Rute Usulan

\begin{tabular}{|c|c|c|c|}
\hline Rute & Rute Usulan & Jarak $(\mathrm{km})$ & Armada \\
\hline 1 & $\mathrm{G} 0 \rightarrow \mathrm{E} \rightarrow \mathrm{G} 0 \rightarrow \mathrm{F} \rightarrow \mathrm{G} 0 \rightarrow \mathrm{C}$ & 776,4 & Avanza \\
\hline 2 & $\mathrm{G} 0 \rightarrow \mathrm{D} \rightarrow \mathrm{G} 0 \rightarrow \mathrm{B} \rightarrow \mathrm{G} 0 \rightarrow \mathrm{A}$ & 1442 & L300 \\
\hline
\end{tabular}

Dari data yang diperoleh, langkah selanjutnya adalah menghitung biaya dengan membandingkan pengeluaran yang dilakukan perusahaan. Apabila jarak yang ditempuh dalam pengiriman rute awal diasumsikan kedalam hasil perhitungan biaya bahan bakar perhari bulan Rp. 334.601, maka besanya biaya yang dikeluarkan dalam satuan kilometer adalah Rp. $6.480 / \mathrm{Km}$

Berikut adalah muatan transportasi yang berdasarkan pada pengusulan penghematan jarak tempuh yang telah dilakukan :

Tabel 4. Kapasitas Transportasi

\begin{tabular}{|c|c|c|c|}
\hline Rute & Kode Rute & Kapasitas & Armada \\
\hline 1 & $\mathrm{G} 0 \rightarrow \mathrm{E} \rightarrow \mathrm{G} 0 \rightarrow \mathrm{F} \rightarrow \mathrm{G} 0 \rightarrow \mathrm{C}$ & 725 & Avanza \\
\hline 2 & $\mathrm{G} 0 \rightarrow \mathrm{D} \rightarrow \mathrm{G} 0 \rightarrow \mathrm{B} \rightarrow \mathrm{G} 0 \rightarrow \mathrm{A}$ & 2750 & L300 \\
\hline
\end{tabular}

Tabel 5. Rekapitulasi Jarak Tempuh Rute Distribusi

\begin{tabular}{|c|c|c|}
\hline Rute & $\begin{array}{c}\text { Total Jarak } \\
\text { Tempuh }(\mathrm{Km})\end{array}$ & Total Biaya \\
\hline Awal & 5401 & Rp 35.003.664 \\
\hline Usulan & 2218 & $\operatorname{Rp~} 14.375 .232$ \\
\hline Selisih & 3183 & Rp 20.628.432 \\
\hline
\end{tabular}

Tabel 6. Rekapitulasi Jarak Tempuh Rute Distribusi

\begin{tabular}{|c|c|c|}
\hline No & Rute & Biaya Transportasi \\
\hline 1 & Bogor & Rp10.601.600 \\
\hline 2 & Lampung & Rp8.278.600 \\
\hline 3 & Jambi & Rp6.289.600 \\
\hline 4 & Bu Ida, Bandara, Medan & Rp9.890.008 \\
\hline
\end{tabular}

Penggunaan metode savings matrix mampu memperbaiki rute distribusi perusahaan dari enam rute menjadi 2 rute sehingga bisa mengurangi biaya operasional perusahaan.mampu memperpendek jarak yang ditempuh angkutan perusahaan dari 5.401,80 KM menjadi 2.218,40 KM. Penggunaan metode savings matrix mampu menghemat pengeluaran perusahaan sebesar $\mathrm{Rp}$ 20.628.432 /Bulan.

\subsection{Perencanaan Rute Distribusi}

Pada tahap ini dilakukan perhitungan dengan menggunakan metode Vehicle Routing Problem (VRP) untuk merencanakan rute yang baru yang nantinya akan digunakan untuk mendistribusikan produk keripik balado ke para konsumen. Terdapat dua armada yang akan mengangkut barang dari gudang menuju konsumen. Berikut adalah rute distribusi keripik balado, yaitu :

Tabel 7. Rute Distribusi Avanza 


\begin{tabular}{|c|c|c|c|c|}
\hline Rute & Kode & Longitutude & Latitude & Demand \\
\hline UKM & Go & 100 & 0.97 & \\
\hline W.Bu Ida & E & 100 & 0.95 & 240 \\
\hline Bandara & F & 100 & 0.78 & 320 \\
\hline Medan & C & 98.67 & 3.59 & 800 \\
\hline
\end{tabular}

Tabel 8. Rute Distribusi L 300

\begin{tabular}{|c|c|c|c|c|}
\hline Rute & Kode & Longitutude & Latitude & Demand \\
\hline UKM & Go & 100 & 0.97 & \\
\hline Jambi & D & 103.64 & 1.57 & 480 \\
\hline Lampung & B & 105.32 & 4.63 & 460 \\
\hline Bogor & A & 106.8 & 6.59 & 700 \\
\hline
\end{tabular}

Perencanaan Mulai Rute pada armada satu adalah armada 1 dengan rute $\mathrm{G} 0 \rightarrow \mathrm{E} \rightarrow \mathrm{F}$ $\rightarrow \mathrm{C}$ dan armada 2 dengan rute $\mathrm{G} 0 \rightarrow \mathrm{D} \rightarrow$ $\mathrm{B} \rightarrow \mathrm{A}$

\subsection{Usulan Perbaikan meninimumkan biaya transportasi}

Langkah-langkah yang diambil untuk memindahakan dan menyimpan produk dari tahap suplier ke tahap pelanggan dalam rantai pasokan adalah pertama, berdasarkan penghematan jarak pada rute awal maka jarak yang ditempuh yaitu $776,4 \mathrm{~km}$ dan rute ke dua jarak yang ditempuh yaitu $1.442 \mathrm{~km}$. Penghematan jarak rute ini dilakukan dengan berdasarkan urutan tempat yang akan ditempuh dan kapasitas armada dalam pengangkutan sehingga lintasan dapat ditempuh dengan satu lintasan sekaligus. Dengan adanya rute awal dan rute ke dua maka armada pengangkutan tidak perlu bolak balik dalam pengantaran barang, hal ini juga dapat menghemat jarak tempuh dan biaya yang dikeluarkan serta waktu dalam perjalanan.

Kedua, menentukan urutan kunjungan setelah alokasi retailer ke rute telah ditentukan. Syarat utamanya adalah dua rute digabung dalam satu rute jika total pengiriman kedua rute tidak melebihi kapasitas alat angkut yang dimiliki perusahaan. Penghematan diatas bisa melakukan alokasi customer ke kendaraan atau rute. Customer - customer tersebut digabungkan sampai batas kapasitas armada yang ada dan tidak melebihi dari kapasitas armada. Penggabungan akan dimulai dari nilai penghematan terbesar karena berupaya memaksimumkan penghematan. Dari perhitungan menggunakan metode Saving Matrix diperoleh 2 rute distribusi sesuai dengan kelompok wilayahnya dengan jarak rute yaitu $1.476 \mathrm{Km}$.

\section{SIMPULAN}

Berikut kesimpulan yang berdasarkan hasil analisis penjadwalan dan penentuan rute distribusi pada rantai pasok untuk meminimasi biaya distribusi dengan menggunakan metode saving matrix di UKM Habil Snack dari hasil penelitian ini adalah untuk penjadwalan dan penentuan rute distribusi pada rantai pasok guna meminimasi biaya distribusi dengan menggunakan Metode Saving Matrix di UKM Habil Snack maka dihasilkan 2 rute distribusi sesuai dengan kelompok wilayahnya dengan jarak rute yaitu 1.476 $\mathrm{Km}$. Untuk merencanakan rute distribusi produk keripik balado dengan menggunakan Vehicle Routing Problem (VRP) di UKM. Habil Snack maka dipilih toko dengan jarak yang terdekat dari toko yang terpilih sebelumnya yaitu sebesar 4,7 $\mathrm{km}$ pada toko dengan kode Bu Ida. Maka toko tersebut terpilih sebagai pelanggan yang dikunjungi

\section{DAFTAR PUSTAKA}

[1] Lubis, A.N. 2004. Peranan Saluran Distribusi Dalam Pemasaran Produk dan Jasa., Jurnal Fakultas Ekonomi Manajemen, Universitas Sumatera utara

[2] Anistya, R. 2014. Penerapan Distribution Requirement Planning (DRP) Pada CV Three J - Bali. Jurnal Ilmiah Mahasiswa Universitas Surabaya, 3 (2)

[3] Adisasmita, Sakti Adji. 2011. Transportasi dan pengembangan wilayah. Yogjakarta: Graha Ilmu.

[4] Kamaluddin. 2003. Ekonomi Transportasi. Jakarta: Ghalia Indonesia. 
[5] Winardi. 1989. Strategi Pemasaran. Bandung: Mandarmaju.

[6] Fisher, M.L. 1995. Vehicle Routing in Operations Research and Management Science, Vol.8. Amsterdam, New York: Elsevier

[7] Saputra, Huda. 2010. Penentuan Rute Pendistribusian Produk Dengan Mneggunakan Metode Generallized
Assiggment untuk Meminimalkan Biaya Transportasi di Songkok Mata Intan dan Shafia Gresik. Tugas Akhir. Fakultas Teknik, Prodi Teknik Industri, Universitas Muhammadiyah Gresik.

[8] Pujawan, I,Y, 2005 Supply Chain Management, Surabaya : Guna Widya 